\title{
Pendidikan Akhlaq Aplikatif-Integratif pada Madrasah Ibtidaiyah di Rubaru Sumenep
}

\author{
Ummi Kulsum \\ (Sekolah Tinggi Ilmu Tarbiyah STIT. Aqidah Usymuni Sumenep) \\ Email: ummikulsumelsyifa85@gmail.com
}

\begin{abstract}
Education of moral is education that is very important to instill moral and spiritual values in life that can foster character, behavior, and good morals for future. If education of moral is not instilled in students from an early age, it does not close the possibility that students will fall into something that is not desired by the wider community. Research on "applicative-integrative education of moral in Madrasah Ibtidaiya Rubaru Sumenep" was carried out because it was based on these concerns.

This research used descriptive-qualitative method with a phenomenological approach, which is by going down directly to the research location to search for the data needed. As for this study the population taken was the whole of students of Madrasah Ibtidaiyah Rubaru Sumenep in the 2018-2019 Academic year by giving a number of questions to students randomly by means of random sampling. The respondents I chose were students in grades 4, 5, and 6 of MI Nurus Salam Pakondang Village, Rubaru District, Sumenep Regency. So the total sample that will be in the data amounted to 35 students. Primary data sources in this study were the results of interviews with school principals, vice curriculim, and moral teachers in MI Nurus Salam, Pakondang village, Rubaru sub-district, Sumenep district.

The results showed a strong commitment from MI Nurus Salam to realize an applicative-integrative moral education in the sense that moral learning does not stop in the area of the concept of knowledge about morals, but there are efforts to internalize, habituate, exemplify, and continue coaching.

Moral development implemented at MI Nurus Salam includes two things: First, by guiding moral behavior through religious activities, such as reciting Asmaul Husna, Yasin letter, followed by Duha prayer 30 minutes before entering class and reading short letters 10 minutes before the lesson begins. This activity is a routine activity that must be followed by every student from grade 1 to grade 6 .

Second, Commemoration of Islamic holidays (PHBI), such as the Birth of the Prophet, Isra 'Mi'raj, ' Ashura, and Ramadan activities, all of these activities as a medium in fostering student morals. In implementing this applicative-integrative moral education, all parties are involved in the routine coordination and monitoring of moral behavior. As a form of evaluation, the value of moral behavior in MI Nurus Salam is coordinated by the homeroom teacher as a report card on the behavior, crafts and neatness based on reports from each teacher.
\end{abstract}

Keywords: Education, Akhlak Aplikative-Integrative 


\section{Pendahuluan}

Akhlak adalah suatu sifat yang tertanam kuat dalam diri yang darinya terlahir perbuatan-perbuatan dengan mudah dan ringan, tanpa perlu berpikir dan merenung. Jika dari sifat tersebut lahir perbuatan-perbuatan yang indah menurut akal dan syari'at dengan mudah, maka sifat tersebut dinamakan akhlak yang baik. Sedangkan jika darinya terlahir perbuatan-perbuatan yang buruk maka disebut akhlak yang buruk. ${ }^{1}$

Upaya pembentukan akhlak manusia juga selaras dengan tujuan pendidikan nasional yang tercantum dalam Sisdiknas No 20 Tahun 2003 Pasal 3, bahwa pendidikan bertujuan untuk mengembangkan potensi peserta didik agar menjadi manusia yang beriman dan bertaqwa kepada Tuhan Yngan Maha Esa, berakhlak mulia, sehat berilmu, cakap, kreatif, mandiri dan menjadi warga yang demokrasi serta bertanggung jawab. ${ }^{2}$

Krisis akhlak yang semula hanya menimpa sebagian kecil elit politik, kini telah menjalar kepada masyarakat 1uas, termasuk kalangan pelajar. Krisis akhlak yang menjadi penyebab timbulnya krisis dalam berbagai bidang kehidupan bangsa Indonesia. Terjadinya dekadensi moral yang menimpa remaja dan anakanak pada zaman global ini merupakan bukti nyata kemerosotan akhlak. Seperti pergaulan bebas, penyalah gunaan narkoba, dan durhaka kepada orang tua, adalah beberapa contoh dan bukti betapa generasi muslim semakin jauh dari nilai-nilai islami.

Belakangan ini umat Islam dilanda dari berbagai masalah, terutama dibidang pendidikan akhlak terhadap peserta didik yang menuntut adanya solusi yang terbaik dalam memecahkan masalah tersebut. Apabila pendidikan akhlak tidak ditanamkan dalam diri peserta didik sejak dini, maka tidak menutup kemungkinan akan menjerumuskan peseta didik pada sesuatu yang tidak diinginkan oleh masyarakat luas. Misalkan ada pelajar yang membentak,

\footnotetext{
${ }^{1}$ Ali Abdul Halim Mahmud, Akhlak Mulia, Terj. Abdul Hayyie al- Kattani, (Jakarta: Gema Insani, 2004), 32

${ }^{2}$ Hasbullah, Dasar-Dasar Ilmu Pendidikan, (Jakarta: PT Raja Grafindo Persada, 2005), 310
} 
memukul bahka berkelahi sama teman-temannya. Hal seperti ini yang tidak kita inginkan, terutama bagi orang tua. Untuk itu perlu dicarikan solusi dan aksi pendidikan akhlak yang tepat. Penelitian mengenai "Pendidikan akhlak aplikatifintegratif di Madrasah Ibtidaiyah Rubaru Kabupaten Sumenep" dilakukan berpijak dari keprihatinan tersebut.

\section{Kajian tentang Akhlak}

1. Konsep Akhlak, Moral, dan Etika.

Secara etimologis, kata akhlak berasal dari bahasa Arab akhlak yang merupakan bentuk jamak dari kata khuluq yang berarti budi pengerti, perangai, tingkah laku atau tabiat. Secara terminologis, akhlak berarti keadaan gerak jiwa yang mendorong ke arah melakukan perbuatan dengan tidak mengkhajatkan pikiran. ${ }^{3}$ Sedangkan menurut al-Ghazali akhlah sebagai suatu sifat yang tetap pada jiwa dari padanya timbul perbuatan-perbuatan dengan mudah, dengan tidak membutuhkan kepada pikiran. ${ }^{4}$ Dengan ini, akhlak dapat diartikan sebagai nilai diri seseorang, yang membedakan antara satu dengan yang lainnya. Jadi, pada hakikatnya akhlak merupakan suatu kondisi atau sifat yang sudah terpatri dalam jiwa dan menjadi kepribadian dalam diri manusia. ${ }^{5}$

Kata akhlak yang berasal dari bahasa Arab akhlaq (yang berarti tabiat, perangai, dan kebiasaan) banyak ditemukan dalam hadits Nabi Saw. salah satunya adalah:

عن ابي هريرة قال قال رسول الله صلى الله عليه وسلم . بعثت لأتمم صالح الأخلاق. (رواه Artinya : "dari Abu Hurairah, ia berkata, Rasulullah saw. bersabda: Sesungguhnya aku diutus untuk menyempurnakan aklak yang mulia”. (HR. Ahmad).

\footnotetext{
${ }^{3}$ Marzuki, Prinsip Dasar Akhlak Mulia: Pengantar Studi Konsep-Konsep Dasar Etika Dalam Islam, (Yogyakarta: Debut Wahana Press, 2009) 8.

${ }^{4}$ Syaikh Ja'far al-Hadi, Mutiara Akhlak Nabi, (Jakarta: Islamic Center Jakarta ALHUDA, 2001), 7

${ }^{5}$ Saproni, Panduan Praktis Akhlak Seorang Muslim, (Bogor: Bina Karya Utama, 2015), 7
} 
Sedangkan dalam al-Qur'an hanya ditemukan bentuk tunggal dari akhlaq yaitu khuluq, sebagaimana ditegaskan dalam surat al-Qalam ayat 4.

$$
\text { و انك لعلى خلق عظيم (القلم: 4) }
$$

Artinya: "Dan sesungguhnya kamu benar-benar berbudi pekerti yang agung”. (Qs. Al-Qalam: (68) 4)

Khuluq adalah ibarat dari kelakuan manusia yang membedakan baik dan buruk, lalu disenangi dan dipilih yang baik untuk dipraktikkan dalam perbuatan, sedangkan yang buruk dibenci dan ditinggalkan.

Dalam khazanah pembendaharaan bahasa Indonesia kata yang setara maknanya dengan akhlak adalah "etika" dan "moral". Kata-kata ini sering disejajarkan dengan budi pekerti, tata susila, tata krama atau sopan santun. Pada dasarnya secara konseptual kata etika dan moral mempunyai pengertian serupa, yakni sama-sama membicarakan perbuatan dan perilaku manusia ditinjau dari sudut pandang nilai baik dan buruk. Akan tetapi dalam aplikasinya etika lebih bersifat teoritis filosofis sebagai acuan untuk mengkaji sistem nilai, sedangkan moral bersifat praktis sebagai tolok ukur untuk menilai perbuatan yang dilakukan oleh seseorang. Etika memandang perilaku secara universal, sedangkan moral secara lokal. ${ }^{6}$

\section{Pendidikan Akhlak Dalam Islam}

Pendidikan akhlak sebagaimana dirumusan oleh Ibn Miskawaih, merupakan upaya ke arah terwujudnya sikap batin yang mampu mendorong secara spontan lahirnya perbuatan-perbuatan yang bernilai dari seseorang. ${ }^{7}$ Dalam pendidikan akhlak ini, kriteria benar dan salah untuk menilai perbuatan yang muncul merujuk kepada al-Qur'an dan Sunnah sebagai sumber tertinggi dalam ajaran Islam. Al-Qur'an menjelaskan kepada kita tentang konsep baik dan buruk dalam berbagai variasi dan keadaan. Untuk menggambarkan masalah kebaikan, al-Qur'an menggunakan term-term seperti shalih, yang berarti baik atau kebaikan.

\footnotetext{
${ }^{6}$ Marzuki, Prinsip Dasar Akhlak Mulia, hal:14. ${ }^{7}$ Sirajuddin Zar, Filsafat Islam: Filosof dan Filsafatnya, (Jakarta: PT Raja Grafindo Persada, 2012), 135.
} 
Kata shalih sering digunakan untuk mensifati amal perbuatan manusia yang baik lawannya kata sayyiah yang berarti jelek. ${ }^{8}$

Kata lain yang digunakan untuk menyebut kebaiakan adalah birr. Dalam al-Qur'an kata birr dimaknai dengan berbagai bentuk perbuatan baik yang meliputi seluruh aspek dalam kerangka ajaran Islam, yakni aqidah, syari’ah, dan akhlak. Dalam hal ini birr identik dengan takwa. ${ }^{9}$ Kata lain yang hampir sama dengan birr adalah qist (adil) lawannya zhulm(aniaya). Kata zhulm jelas menunjukkan suatu bentuk keburukan yang dapat terealisasi dalam berbagai bentuk perbuatan manusia, baik terhadap sesamanaya maupun terhadap Allah. Kata lain yang menunjukkan keburukan adalah fasad yang merupakan kata yang sangat konprehensif yang menunjukkan semua jenis pekerjaan yang buruk. ${ }^{10}$

Al-Qur'an juga menggunakan kata ma'ruf dan munkar untuk menunjukkan baik dan buruk. Kata ma'ruf, yang arti umumnya baik, sering digunakan untuk menyebut apa yang diakui dan diterima oleh syari'ah. Dan untuk menyebut apa yang tidak diakui atau bertentangan dengan syari'ah, al-Quran menggunakan kata munkar selain kata munkar al-Qur'an juga menggunakan kata fahsya' atau fahisyah untuk menyebut keburukan. ${ }^{11}$

Di samping itu, al-Quran juga menggunakan kata khair untuk menyebut kebaikan dan kata syarr untuk menyebut keburukan. Khair merupakan sebuah istilah yang sangat komprehenshif yang mengartikan segala apapun yang dapat dinilai sebagai bernilai tinggi, menguntungkan, bermanfaat, dan dikehendaki Kata lain yan berarti kebaikan adalah hasan, hasanah, atau ahsan lawannya sayyiah atau su' yang berarti buruk atau jelek. Al-Qur'an juga menggunakan kata thayyib untuk menyeut kebaikan dan khabits untuk menyebut keburukan (kotoran). Akhirnya, al-Qur'an juga menggunakan kata halal dan haram untuk menunjukkan adanya kebaikan dan keburukan.

\footnotetext{
${ }^{8}$ Qs. Al-'Ashr: 3.

${ }^{9}$ Qs. Al-Baqarah : 177.

${ }^{10}$ Marzuki, Prinsip Dasar Akhlak Muli, hal:15.

${ }^{11}$ Qs. Ali Imron: 104 dan 110, Qs. At- Taubah: 71, Al-A'raf: 157,
} 
Semua kata yang digunakan untuk menyebut adanya dua sifat yang bertentangan, baik dan buruk, seperti di atas bahwa baik dan buruk menunjukkan kunci dari pensifatan terhadap perbuatan manusia dalam berbagai aspek kehidupan. Variasi bentuk kata itu dapat dipahami juga sebagai spesifikasi dari berbagai bentuk perbuatan manusia yang bernilai baik dan bernilai buruk. Yang baik dihukumi halal untuk dikerjakan dan yang buruk dihukumi haram untuk tidak dikerjakan. Dua sifat itu tercermin dalam bentuk perilaku yang positif (akhlak mulia) dan perilaku yang negatif (akhlak tercela). Ukuran yang paling pokok untuk membedakan perilaku ini adalah masalah keimanan kepada Allah, pencipta seluruh makhluk. $^{12}$

Pendidikan akhlak secara umum dibedakan menjadi dua kategori, yaitu pendidikan akhlak rasional dan pendidikan akhlak mistik. Perbedaan kedua jenis pendidikan akhlak tersebut berimplikasi pada tumbuhnya kreativitas dan inisiatif bagi akhlak rasional dan sebaliknya akhlak mistik kurang memotivasi manusia untuk aktif, kreatif, dan dinamis. Hal tersebut disebabkan adanya perbedaan pendekatan. Pendidikan akhlak rasional dari pendekatan ajaran Islam yang bukan semata sebagai doktrin yang absolut(pendekatan kemanusiaan). Sementara itu, pendidikan akhlak mistik melakukan pendekatan terhadap ajaran Islam sebagai ajaran yang absolut (pendekatan ketuhanan). Pendekatan kemanusiaan memiliki indikasi manusia bersifat otonom, sedangkan pendekatan ketuhanan menempatkan manusia pada makhluk yang heteronom. ${ }^{13}$

Dalam pendidikan Islam, tidak ada disiplin ilmu yang terpisah dari etika-etika Islam dan pentingnya komparasi antara akal dan wahyu dalam menentukan nilai-nilai moral terbuka untuk diperdebatkan. Bagi kebanyakan muslim segala yang dianggap halal dan haram dalam Islam, dipahami sebagai keputusan Allah tentang benar dan baik. Dalam Islam terdapat tiga nilai utama, yaitu akhlak, adab, dan keteladanan. Akhlak merujuk kepada tugas dan tanggung jawab selain syari'ah dan ajaran Islam secara umum. Sedangkan adab merujuk

\footnotetext{
${ }^{12}$ Marzuki, Prinsip Dasar Akhlak Muli, 27-30

${ }^{13}$ Harun Nasution, Muhammad Abduh dan Teologi Rasional Mu'tazilah, (Jakarta: UI Press, 1987), $1-5$.
} 
kepada sikap yang dihubungkan dengan tingkah laku yang baik. Dan keteladanan merujuk pada kualitas karakter yang ditampilkan oleh seorang muslim yang baik yang mengikuti keteladanan Nabi Muhammad Saw. Ketiga nilai inilai yang menjadi pilar pendidikan akhlak dalam Islam. ${ }^{14}$

Dengan ini dapat diambil kesimpulan, bahwa hubungan akhlak dengan pendidikan sangat erat. Pendidikan dalam pandangan Islam berhubungan dengan kualitas manusia yang berakhlak, karena tujuan pendidikan sendiri adalah identik dengan tujuan hidup seorang muslim, yaitu menjadi hamba Allah swt. yang mengandung implikasi kepercayaan dan penyerahan diri kepada-Nya dengan mencapai suatu akhlah yang sempurna merupakan tujuan sebenarnya dari pendidikan.

\section{Pendidikan Akhlak Aplikatif-Integratif}

Membahas pendidikan akhlak berarti mengupas tentang upaya pembentukan akhlak mulia melalui proses pendidikan. Menurut Abuddin Nata, akhlak merupakan hasil usaha dan melatih dengan sungguh-sungguh terhadap segala potensi rohaniyah yang terdapat dalam diri manusia. Jika program pendidikan dan pembinaan akhlak dirancang dengan baik, sistimatis, dan dilaksanakan sungguh-sungguh, akan menghasilkan anak-anak dan orang-orang yang berakhlak mulia. Di sinilah letak peran dang fungsi lembaga pendidikan. Menurut beliau, pendidikan akhlak sebagai upaya yang menyangkut perilaku akhlak, maka segala bentuk pembelajaran akhlak harus berorentasi pada aplikasi perilaku-perilaku baik (al-akhlaq al-karimah). ${ }^{15}$ Hal ini senada dengan apa yang disampaikan oleh Ibn Miskawaih, ia menegaskan bahwa akhlak hanya dapat dibentuk melalui pendidikan dan pembiasaan. Ia menolak anggapan bahwa anakanak akan berkembang sesuai perkembangannya tanpa pembiasaan dan pendidikan. $^{16}$

\footnotetext{
${ }^{14}$ Yunus Amyn, Ontologi Kajian Islam: Pendidikan Akhlaq Aplikatif-Integratif di Mts. Dan SMPN Kabupaten Jember, (Surabaya: Pasca Sajana IAIN Sunan Ampel Press, 2009), 176.

${ }^{15}$ Abuddin Nata, Akhlak Tasawuf (Jakarta: RG Persada, 2006), 158.

${ }^{16}$ Sirajuddin Zar, Filsafat Islam: Filosof dan Filsafatnya, 136.
} 
Maka melakukan proses pendidikan akhlak tidak cukup melalui bidang studi saja tetapi mencakup bidang studi secara keseluruhan, bahkan mencakup seluruh program pendidikan secara integratif. Sesuai hasil rumusan Kemendiknas dan kemenag menyimpulkan bahwa pendidikan akhlak bukan merupakan mata pelajaran tersendiri, tetapi merupakan program pendidikan terpadu yang memerlukan prilaku, keteladanan, pembiasaan, bimbingan, dan penciptaan lingkungan moralitas yang kondusif. ${ }^{17}$

Dengan memasukkan character-based approach sebagai upaya membangun karakter peserta didik yang berbudi luhur secara bersama-sama. Inilah bentuk upaya mengupayakan proses pendidikan akhlak secara integratif yang menjadi bagian penting dari pengembangan kurikulum 2004 yang bercorak KBK (Kurikulum Berbasis Kompetensi) menjadi KTSP (Kurikulum Tingkat Satuan Pendidikan) pada 2006 dan menjadi tugas penting bagi sekolah untuk melakukan inprovisasi guna meningkatkan mutu pendidikan, terutama dalam menanamkan dan membentuk kebiasaan ber akhlak mulia bagi peserta didik. Pada tahun 2013 disempurnakan dengan kurikulum yang mengintegrasikan pendidikan karakter dalam setiap pelajaran. ${ }^{18}$

Desain pendidikan akhlak atau pengembangan karakter di sekolah menjadi empat desain, yaitu: pertama, mengintegrasikan ke setiap mata pelajaran untuk memperkenalkan nilai-nilai akhlak disetiap mata pelajaran. Nilai-nilai tersebut dicantumkan dalam silabus dan RPP. Kedua, pengembangan budaya sekolah dengan membentuk akhlak siswa melalui kegiatan-kegiatan seperti kegiatan kurikuler, proses mengambil keputusan, dan kebijakan. Ketiga, melalui kegiatan ekstrakurikuler yang merupakan kegiatan sekolah yang ada di luar sekolah dan di luar mata pelajaran yang bertujuan untuk membentuk kreativitas siswa untuk bisa menyalurkan bakat dan minat dalam rangka mendukung

\footnotetext{
${ }^{17}$ Darmiyati Zuchdi dkk. Panduan Implementasi Pendidikan Karakter Terintigrasi Dalam Dalam Pembelajaran dan Pengembangan Kultur Sekolah, (Yogyakarta: UNY Press, 2012), 18.

${ }^{18}$ Ahmad Royani, pendidikan Akhlak Aplikatif Integratif di Sekolah, (Fenomena: Vol 14 No 1 April 2015), 16.
} 
kemandirian siswa. Keempat, berbasis komunitas dimana sekolah melibatkan orang tua dan masyarakat dalam membentuk akhlak peserta didik.

Berdasarkan paparan di atas, bahwa sistem pendidikan di sekolah untuk mengembangkan pendidikan akhlak peserta didik, Pendidik harus diposiskan atau memposisikan diri pada hakekat yang sebenarnya, yaitu: Pertama, Pendidik merupakan pengajar dan pendidik, artinya selain mentransfer ilmu pengetahuan, juga mendidik dan mengembangkan kepribadian peserta didik melalui intraksi yang dilakukannya di kelas dan di luar kelas. Kedua, pendidik hendaknya diberikan hak penuh dalam melakukan penilaian atau evaluasi proses pembelajaran, karena Pendidik merupakan pihak yang paling mengetahui tentang kondisi dan perkembangan peserta didiknya. Ketiga, Pendidik hendaknya mengembangkan sistem evaluasi yang lebih menitik beratkan pada aspek afektif, dengan menggunakan alat dan bentuk penilaian essay dan wawancara langsung dengan peserta didik, sehingaa dapat mengukur karakteristik setiap peserta didik, serta mampu mengukur sikap kejujuran, kemandirian, kemampuan berkomunikasi, dan lain sebagainya. ${ }^{19}$ Dengan demikian, pendidikan akhlak aplikatif-integratif ini dapat terlaksana dengan baik jika semua elemen dapat mendukung dan bekerja sama baik orang tua, pendidik, maupun pemerintah selaku pemegang kebijakan.

\section{Metode Penelitian}

1. Jenis dan Pendekatan Penelitian

Penelitian ini menggunakan metode deskriptif-kualitatif dengan pendekatan fenomenologis, yaitu dengan cara turun langsung ke lokasi penelitian untuk melakukan pencarian data yang dibutuhkan. ${ }^{20}$ Fokus penelitian ini berkaitan dengan pendidikan akhlak secara aplikatif-integratif, maka pendekatan yang cocok digunakan adalah pendekatan kualitatif. Penulis mengambil pendekatan

\footnotetext{
${ }^{19}$ Ahmad Royani, pendidikan Akhlak Aplikatif Integratif di Sekolah, 17

${ }^{20}$ Lexi J. Moloeng, Metodologi Penelitian Kualitatif, (Bandung: PT Remaja Rosdakarya, 2006), 9.
} 
tersebut untuk mengamati objek penelitian di lapangan, yakni bagaimana pendidikan akhlak aplikatif-integratif yang ada di Madrasah Ibtidaiyah Rubaru Sumenep, dengan fokus masalah menyangkut bagaimana proses pendidikan akhlak di lembaga tersebut.

2. Populasi dan Sampel

a) Populasi

Populasi adalah kelompok besar dan wilayah yang menjadi lingkup penelitian. ${ }^{21}$ Populasi terdiri atas sekumpulan objek yang menjadi pusat perhatian, yang dari padanya terkandung informasi yang ingin diketahui. Adapun dalam penelitian ini populasi yang diambil adalah keseluruhan dari siswa/i Madrasah Ibtidaiyah Rubaru Sumenep pada tahun Pelajaran 2018-2019. Karena penelitian ini tidak dilakukan untuk meneliti semua individu dalam populasi, maka untuk meneliti objek yang akan diteliti diwakilkan oleh sebagian populasi yaitu menggunakan sampel.

\section{b) Sampel}

Sampel adalah kelompok kecil bagian dari target populasi yang mewakili populasi dan secara riil diteliti. ${ }^{22}$ Penarikan sampel dalam penelitian ini yaitu dengan memberikan sejumlah pertanyaan kepada siswa secara acak dengan cara random sampling. Teknik random sampling ini yaitu dengan memberikan sejumlah pertanyaan kepada siswa secara acak dengan cara memilih responden. Responden yang peneliti pilih yaitu siswa/i pada kelas 4, 5, dan 6 MI Nurus Salam Desa Pakondang Kecamatan Rubaru Kabupaten Sumenep. Jadi total sampel yang akan di data berjumlah 35 siswa.

\section{Sumber Data}

Sumber data yang digunakan dalam penelitian ini terdiri dari sumber data primer dan sumber data sekunder. Sumber data primer dalam penelitian ini adalah hasil wawancara dengan kepala sekolah, waka kurikulim, guru akidah

\footnotetext{
${ }^{21}$ Nana Syaodih Sukmadinata, Metode Penelitian Pendidikan, (Bandung: PT RemajaRosdakarya, 2013), 250.

${ }^{22}$ Ibid; 266.
} 
akhlak, dan siswa/i kelas 4,5, dan 6 di MI Nurus Salam Pakondang Rubaru Sumenep. Adapun sumber data sekunder adalah berbagai dokumen yang mendukung atau literatur yang relevan dengan permasalahan penelitian seperti buku, jurnal, dan catatan.

\section{Metode Pengumpulan Data}

Sedangkan metode pengumpulan data yang digunakan dalam penelitian ini meliputi pertama; observasi, kedua; wawancara, dan ketiga; dokumentasi. Pertama, Metode observasi yang peneliti gunakan adalah observasi partisipan yaitu dengan ikut aktif secara langsung ke dalam objek yang akan diteliti, yaitu peneliti mengikuti kegiatan yang ada di MI Nurus Salam, seperti shalat berjama'ah, dan belajar bersama, sehingga peneliti bisa mengetahui secara langsung proses pendidikan akhlak di lembaga tersebut.

Kedua, metode wawancara atau interview yang peneliti gunakan adalah interview bebas terpimpin dengan mempersiapkan terlebih dahulu beberapa pokok pertanyaan yang akan diajukan kepada responden. Metode ini digunakan untuk memperoleh data yang dibutuhkan, yaitu metode pengajaran yang diterapkan dalam pembinaan akhlak siswa, faktor pendukung dan penghambat dalam pembinaan akhlak siswa tersebut. Ketiga, metode dokumentasi. ${ }^{23}$ Metode ini digunakan untuk memperoleh data yang sekiranya tidak diperoleh dengan metode observasi dan interview, seperti pembinaan akhlak siswa dalam bentuk dokumen, kegiatan siswa dalam bentuk dokumen, dan segala sesuatu yang berhubungan dengan penelitian ini.

\section{Metode Analisis Data}

Ada dua data yang diperoleh dalam penelitian kualitatif, pertama adalah data dari proses wawancara secara mendalam, sedangkan yang kedua data deskriptif yang ada dalam catatan lapangan (field note) dan di dokumen. Data primer dari hasil wawancara merupakan data deskriptif yang kemudian penulis

\footnotetext{
${ }^{23}$ Sugiono, Metode Penelitian Kuantitatif, Kualitatif dan R \& D ( Bandung : CV. Alfabeta, IKAPI, 2012), 145
} 
konstruk melalui pendekatan fenomenologis, yaitu dengan cara turun langsung ke lokasi penelitian untuk melakukan pencarian data yang dibutuhkan.

Adapun data dari field note digunakan untuk menggambarkan kondisi umum pendidikan akhlak di MI Nurus Salam, sedangkan data dokumentasi berguna untuk menunjang atau melengkapi deskripsi tersebut. Pertama, yang akan dilakukan dari rekaman wawancara adalah mentraskrip hasil wawancara. Kedua, adalah memberi label pada informasi-informasi yang didapat dalam wawancara. Labeling atau coding ini adalah memberi kategori-kategori dari data yang diperoleh dari beberapa narasumber, sehingga mudah untuk diklasifikasi.

Ketiga, dalam analisis data kualitatif adalah penarikan kesimpulan dan verifikasi. Kesimpulan awal yang dikemukakan masih bersifat sementara, dan akan berubah bila ditemukan bukti-bukti yang kuat yang mendukung pada tahap pengumpulan data berikutnya. ${ }^{24}$

\section{Hasil penelitian}

1. Pembinaan Akhlak Aplikatif-Integratif Pada Siswa

Hasil penelitian menunjukkan adanya komitmen kuat dari MI Nurus Salam tersebut untuk mewujudka pendidikan akhlak yang aplikatif-integratif dalam pengertian bahwa pembelajaran akhlak yang dilakukan tidak berhenti pada wilayah konsep pengetahuan tentang akhlak, tetapi ada upaya internalisasi, pembiasaan, keteladanan dan pembinaan berkesinambungan. ${ }^{25}$

Secara etimologi, pembiasaan asal katanya adalah biasa. Dalam kamus bahasa Indonesia biasa adalah lazim atau umum, seperti sedia kala. Dengan adanya prefiks pe- dan sufiks-an menunjukkan proses. Sehingga pembiasaan dapat diartikan dengan proses membuat sesuatu atau seseorang menjadi terbiasa. Pembiasaan dapat diartikan dengan proses membuat sesuatu atau membuat seseorang menjadi terbiasa. Pembiasaan dapat juga diartikan sebagai cara yang

\footnotetext{
${ }^{24}$ Sugiono, Metode Penelitian Pendidikan, (Bandung : CV.ALFABETA 2008), 338.

${ }^{25}$ Wawancara dengan bpk Moh. Hasan, S.Pd.I (Kepala Sekolah), 23-12-2019.
} 
dapat dilakukan untuk membiasakan peserta didik berpikir, bersikap, dan bertindak sesuai dengan tuntunan ajaran agama Islam. ${ }^{26}$

Metode pembiasaan perlu diterapkan oleh guru dalam proses pembentukan karakter, untuk membiasakan peserta didik dengan sifat-sifat terpuji dan baik, sehingga aktivitas yang dilakukan oleh peserta didik terekam secara positif. Pendidikan melalui pembiasaan dapat dilaksanakan sebagai berikut:

a. Kegiatan pembiasaan secara terprogram dapat dilaksanakan sebagai berikut:

1) Rutin, yaitu pembiasaan yang dilakukan terjadwal. Di MI Nurus Salam metode ini diterapkan melalui kegiatan-kegiatan. Pertama, ekstra kurikuler seperti upacara bendera yang dilaksanakan setiap hari senin, senam sehat dilaksanakan pada hari sabtu. Kedua, kegiatan-kegiatan keagamaan, seperti baca asmaul husna, surat Yasin, dilanjutkan dengan sholat dhuha berjama'ah 30 menit sebelum masuk kelas dan baca surat-surat pendek 10 menit sebelum pelajaran dimulaui. Kegiatan ini merupakan kegiatan rutin yang harus diikuti oleh setiap siswa dari kelas 1 sampai kelas 6. Ketiga, Peringatan hari besar Islam (PHBI), seperti Maulid Nabi, Isra' Mi'raj, 'Asyura, dan kegiatan Ramadhan, semua kegiatan ini sebagai media dalam membina akhlak siswa.

2) Spontan adalah pembiasaan tidak terjadwal dalam kejadian khusus. Di MI Nurus Salam metode ini diterapkan melalui pembentukan perilaku, seperti memberi salam, pemeliharaan kebersihan, dan kesehatan seperti membuang sampah pada tempatnya.

3) Keteladanan adalah pembiasaan dalam bentuk perilaku seharihari. Ada dua syarat harus dipenuhi. Pertama, guru atau orang tua harus berperan sebagai teladan yang baik bagi siswa dan

\footnotetext{
${ }^{26}$ Armai Arief, Pengantar Ilmu Dan Metodologi Pendidikan Islam, (Jakarta: Ciputat Pers, 2002), 110.
} 
anak-anak. Kedua, siswa atau anak-anak harus meneladani figur-figur terkenal yang berakhlak mulia, seperti Nabi Muhammad saw. ${ }^{27}$ Keteladanan dalam pembiasaan perilaku sehari-hari seperti berpakaian rapi, berbahasa yang baik, dan datang tepat waktu. Mengenai sikap teladan guru Aqidah Akhlak di MI Nurus Salam, hasilnya sebagian besar siswa mengatakan bahwa guru aqidah akhlak mereka selalu menerapkannya. ${ }^{28}$

Dalam melaksanakan pendidikan akhlak aplikatif-integratif ini, semua pihak dilibatkan dalam kordinasi dan pemantauan perilaku akhlak secara rutin. Sebagai bentuk evaluasi, nilai perilaku akhlak di MI Nurus Salam dikordinir wali kelas sebagai nilai raport unsur kelakuan, kerajinan, dan kerapian berdasarkan laporan dari tiap guru. ${ }^{29}$

\section{Faktor Pendukung}

Membahas pendidikan akhlak berarti menelaah tentang pembentukan akhlak mulia melalui seluruh proses pendidikan. Abuddin Nata menjelaskan bahwa akhlah merupakan hasil usaha dalam mendidik dan melatih dengan sungguh-sungguh terhadap segala potensi rohaniyah yang terdapat pada diri manusia. Jika program pendidikan dan pembinaan akhlak dirancang dengan baik, sistematis, dan dilaksanakan dengan sungguh-sungguh, akan menghasilkan anakanak dan orag-orang yang baik akhlaknya.

Maka dengan ini, pendidikan akhlak aplikatif-integratif tidak cukup hanya dengan meletakkan dasar kebaikan perilaku dalam seluruh bidang studi dan menjadikannya sebagai satu kesatuan sistematis dalam membangun karakter peserta didik. Tidak cukup pula menciptakan lingkungan yang dapat menumbuhkan budi pekerti luhur hanya di sekolah, tetapi juga harus menciptakan lingkungan akhlak mulia ini terutama di lingkungan keluarga dan masyarakat,

\footnotetext{
${ }^{27}$ Darmiyati Zuchdi dkk. Panduan Implementasi Pendidikan Karakter, 11

${ }^{28}$ Hasil angket siswa/i

${ }^{29}$ Wawancara dengan guru Akidah Akhlak (Ustd, Mansur), 23-12-2019.
} 
sehingga pendidikan akhlak aplikatif-integratif yang melibatkan pihak menjadi tanggung jawab bersama antara keluarga, sekolah, dan masyarakat. ${ }^{30}$

a) Keluarga, faktor pendukuang adalah orang tua yang selalu membimbing dan memberikan contoh yang baik terhadap anakanaknya dalam aktivitas sehari-hari di dalam keluarga, seperti sikap orang tua kepada anak-anaknya, sikap ayah kepada ibu, sikap ibu kepada ayahnya, serta sikap orang tua kepada tetangga. Sikap orang tua sangat mempengaruhi tinggah laku anak, karena perkembangan sikap sosial anak dimulai di dalam keluarga.

b) Guru/pendidik, guru adalah salah satu faktor pendidikan yang sangat penting, karena pendidik merupakan orang yang akan bertanggung jawab dalam pembentukan pribadi peserta didik selama berada di lingkungan sekolah. Guru harus mampu menunjukkan akhlakul karimah dalam kehidupan sehari-hari, karena peran dan pengaruh seorang guru terhadap peserta didik sangat kuat.

c) lingkungan / masyarakat, lingkungan adalah salah satu faktor yang sangat penting juga dalam pendidikan akhlak. Sebaik apapun pembawaan, kepribadian, keluarga, pendidikan yang ditempuh, tanpa didukung oleh lingkungan yang kondusif, maka akhlak yang baik tidak akan terbentuk.

\section{Faktor Penghambat}

a) kesibukan orang tua, pengaruh kemajuan ilmu pengetahuan dan teknologi serta pola hidup materialis dan pragmatis menyebabkan orang tua selalu disibukkan dengan karir masing-masing. Sehingga mereka kurang memberikan perhatian dan kasih sayang kepada anak-anaknya.

\footnotetext{
${ }^{30}$ Yunus Amyn, Ontologi Kajian Islam, 178.
} 
b) sikap orang tua, selain kurangnya perhatian yang diberikan orang tua kepada anak. Para orang tua juga masih banyak yang berpandangan sempit mengenai pendidikan. Masih banyak orang tua yang beranggapan bahwa pendidikan agama khususnya pendidikan akhlak cukup diberikan dilembaga formal (sekolah) atau guru ngaji yang ada di lingkungan sekitar.

c) lingkungan, interaksi anak dengan lingkungan tidak dapat dielakkan, karena anak membutuhkan teman bermain dan kawan sebaya untuk bisa diajak bicara sebagai bentuk sosialisasi. Sedikit banyak informasi yang diterima akan terekam dibenak anak. Lingkungan rumah serta lingkungan pergaulan anak yang jauh dari nilai-nilai islami, lambat laun akan dapat melunturkan pendidikan agama khususnya pendidikan akhlak yang telah ditanamkan baik di rumah maupun di sekolah.

d) media massa, kemajuan ilmu pengetahuan dan teknologi (IPTEK) telah menciptakan perubahan besar dalam kehidupan ini. Televisi atau media massa lain yang lahir dari kemajuan IPTEK telah banyak memberikan dampak negatif kepada perkembangan anak, terutama dalam pembentukan pribadi dan karakter anak.

\section{Kesimpulan}

Setelah melakukan penelitian di MI Nurus Salam mengenai Pendidikan Akhlak Aplikatif-Integratif, maka dapat diambil kesimpulan sebagai berikut:

1. Proses pendidikan akhlak di MI Nurus Salam dilaksanakan melalui aplikasi kurikulum formal dari beberapa bidang studi agama yang meliputi Aqidah Akhlak, al-Qur'an Hadis, Fiqih, dan SKI disamping secara informal juga diupayakan bagi setiap guru bidang studi lain, untuk melakukan pembinaan dan pembiasaan nilai-nilai akhlak terpuji. 
2. Semua unsur tenaga pendidik dan tenaga kependidikan turut andil dalam upaya pembinaan akhlak siswa dengan peran masing-masing

3. Pola pendidikan akhlak di MI Nurus Salam, pembinaan dan penguatan aspek afektif melalui penerapan nilai-nilai akhlak lebih sering dilakukan oleh guru bidang studi Agama, namun setiap guru melakukan kordinasi perilaku akhlak sebagai acuan penilaian siswa dari unsur kelakuan, kerajinan, dan kerapian.

\section{Daftar Pustaka}

Hasbullah, Dasar-Dasar Ilmu Pendidikan, 2005, Jakarta: PT Raja Grafindo Persada.

Al-Hadi Syaikh Ja'far, 2001, Mutiara Akhlak Nabi, Jakarta: Islamic Center Jakarta ALHUDA.

Mahmud Ali Abdul Halim, 2004, Akhlak Mulia, Terj. Abdul Hayyie al- Kattani,, Jakarta: Gema Insani.

Marzuki, 2009, Prinsip Dasar Akhlak Mulia: Pengantar Studi Konsep-Konsep Dasar Etika Dalam Islam, Yogyakarta: Debut Wahana Press.

Moloeng, Lexi J. 2006, Metodologi Penelitian Kualitatif, Bandung: PT Remaja Rosdakarya.

Nata Abuddin, 2006, Akhlak Tasawuf ahlak, Jakarta: RG Persadar

Syaodih Sukmadinata , 2013, Metode Penelitian Pendidikan, Bandung: PT RemajaRosdakarya.

Sugiono, 2012, Metode Penelitian Kuantitatif, Kualitatif dan R \& D, Bandung : CV. Alfabeta, IKAPI.

Sugiono, 2008, Metode Penelitian Pendidikan, Bandung : CV.ALFABETA.

Saproni, 2015, Panduan Praktis Akhlak Seorang Muslim, Bogor: Bina Karya Utama.

Zar Sirajuddin, 2012, Filsafat Islam: Filosof dan Filsafatnya, Jakarta: PT Raja Grafindo Persada. 
322 - 322 | Tafhim Al-'Ilmi, Februari 2020

Zuchdi Darmiyati dkk. 2012, Panduan Implementasi Pendidikan Karakter Terintigrasi Dalam Dalam Pembelajaran dan Pengembangan Kultur Sekolah, Yogyakarta: UNY Press.

Nasution Harun, 1987, Muhammad Abduh dan Teologi Rasional Mu’tazilah, Jakarta: UI Press.

Amyn Yunus, 2009, Ontologi Kajian Islam: Pendidikan Akhlaq AplikatifIntegratif di Mts. Dan SMPN Kabupaten Jember, Surabaya: Pasca Sajana IAIN Sunan Ampel Press. 